\title{
ANALISIS PENGANGGURAN DAN KESEMPATAN KERJA DI MASA PANDEMI COVID-19
}

\author{
Bayu Surindra', Martia Winda Artantri ${ }^{2}$, Rr. Forijati ${ }^{3}$, M. Anas $^{4}$ \\ bayusurindra@unpkediri.ac.id11,windamartia@gmail.com², \\ forijati@unpkediri.ac.id ${ }^{3}$, anas@unpkediri.ac.id ${ }^{4}$ \\ Program Studi Pendidikan Ekonomi, FEB, Universitas Nusantara PGRI Kediri ${ }^{1}$ \\ Magister Pendidikan Ekonomi, Pascasarjana, Universitas Nusantara PGRI Kediri2,3,4
}

\begin{abstract}
Abstrak
Melakukan snalisis pengangguran dan kesempatan kerja yang ada di Indonesia terutama pada masa pandemi covid 19 merupakan tujuan dalam penelitian ini. Metode penelitian dalam penelitian ini menggunakan analisis deskriptif, dimana data berasal dari data sekunder yaitu data yang sudah disediakan oleh BPS (Badan Pusat Statistik). Hasil penelitian menunjukkan Pada tahun 2018 sampai 2020 , tingkat pengangguran terbuka berdasarkan jenis kelamin didominasi oleh laki-laki dan rata-rata pengangguran terbuka pada tahun 2020 sampai tahun 2021 meningkat menjadi 6,26\%.
\end{abstract}

Kata Kunci: Pengangguran, Kesempatan Kerja, Pandemi Covid-19

\section{PENDAHULUAN}

Pandemi Covid 19 membawa berbagai permasalahan di masyarakat salah satunya mengenai peningkatan pengangguran dan kesempatan kerja yang semakin sulit. Tingkat pengangguran merupakan suatu keadaan yang menunjukkan jumlah angkatan kerja yang tidak bekerja dan aktif mencari pekerjaan (BPS, n.d.). Pengangguran merupakan sebutan bagi seseorang yang tidak memiliki pekerjaan, lagi mencari pekerjaan, pekerjaan yang dilakukan kurang dari 2 hari sepanjang seminggu, ataupun seorang yang lagi berupaya memperoleh pekerjaan yang dianggap layak (Wikipedia, 2021). Biasanya pengangguran diakibatkan jumlah lapangan pekerjaan yang tidak sebanding dengan Angkatan kerja.

Beberapa jenis pengangguran menurut (Jalil et al., 2020), antara lain: 1)Pengangguran terbuka: pengangguran karena belum memperoleh pekerjaan maupun karena enggan untuk kerja; 2)Pengangguran terselubung: pengangguran akibat produktivitas tenaga kerja rendah atau belum optimal; 3)Pengangguran siklikal: pengangguran yang terjadi akibat perubahan kondisi ekonomi negara; 4)Pengangguran struktural: pengangguran akibat perubahan suatu keterampilan terbaru; 5)Pengangguran friksional: pengangguran akibat kesulitan antara pihak penyedia lapangan kerja dengan pencari kerja; 6)Pengangguran teknologi: pengangguran akibat adanya teknologi yang berkembang sehingga mesin menggantikan tenaga manusia; 7)Pengangguran musiman, merupakan pengangguran akibat siklus ekonomi ataupun pergantian musim.

Pengangguran sangat erat kaitannya dengan kesempatan kerja. Kesempatan kerja merupakan jumlah keseluruhan tenaga kerja yang dapat diterima dalam perekonomian (Putu \& Sudibia, 2018) (Ahmaddizon \& Aimon, 2020). Kesempatan kerja sama dengan permintaan tenaga kerja, sama dengan jumlah lowongan kerja yang ada di dunia kerja (Neka et al., 2015). Peluang kerja terpaut dengan kehidupan ekonomi yang senantiasa dinamis (Arifin \& Firmansyah, 2017). Beberapa faktor yang mempengaruhi kesempatan kerja, antara lain: 1)inflasi, yaitu merupakan adanya peningkatan harga yang cenderung terjadi secara terus menerus; 2)tingkat upah, dimana semakin tinggi tingkat upah suatu dareha maka akan menyebabkan daerah tersebut semakin diserbu oleh para pencari kerja; 
3)tingkat pertumbuhan ekonomi, dimana dengan adanya peningkatan pertumbuhan ekonomi maka akan meningkatkan pula stnadar hidup masyarakat (Dona et al., 2018).

Indikator kesempatan yaitu banyaknya orang yang ditampung buat bekerja pada sesuatu lapangan pekerjaan serta tersedianya lapangan pekerjaan yang ada (Hardini, 2017). Semakin besar serta semakin luas kesempatan kerja yang tersedia maka semakin besar pengangguran bisa menurun (Chandra et al., 2020). Kesempatan kerja dapat dikelompokkan ke dalam dua kategori, antara lain: 1)Peluang kerja permanen, ialah peluang kerja yang membolehkan seorang bekerja secara terus menerus hingga mereka pensiun dan 2)Peluang kerja temporer, ialah peluang kerja yang membolehkan seorang yang bekerja namun dalam waktu yang relatif pendek, setelah itu menganggur buat menunggu peluang kerja baru (Yasrizal \& Hasan, 2017).

Beberapa penyebab pengangguran di Indonesia, antara lain: 1)Jumlah tenaga kerja serta jumlah lapangan pekerjaan yang tidak seimbang; 2)Kemajuan teknologi sehingga manusia tergantikan oleh mesin; 3)Keahlian serta pengalaman yang dipunyai tidak sesuai kriteria; 4)Minimnya pembelajaran/ pendidikan; 5)Kemiskinan; 6)Pemutusan ikatan kerja; 7)Tempat tinggal yang jauh dari domisili; 8)Kalah dalam persaingan pasar global; 9)Kesusahan mencari lowongan kerja (Jalil et al., 2020). Pengangguran menjadi permasalahan dalam perekonomian, Dengan terdapatnya pengangguran, produktivitas masyarakat menurun sehingga dapat menimbulkan kemiskinan serta masalah- masalah sosial lain. Pengangguran merupakan sesuatu kondisi dimana seorang yang terkategori angkatan kerja mau memperoleh pekerjaan namun belum bisa mendapatkannya (Permadhy, 2020).. Point artikel ini adalah menganalisis pengangguran dan kesempatan kerja di Indonesia terutama pada masa pandemi Covid 19.

\section{METODE PENELITIAN}

Penelitian ini menggunakan metode analisis deskriptif, dimana data berasal dari data sekunder yang tersedia dari data BPS (Badan Pusat Statistik). Sampel yang dipakai dalam penelitian yaitu pengangguran dan kesempatan kerja yang ada di Indonesia mulai tahun 2017-2020.

\section{PEMBAHASAN}

Pengagguran di Indonesia dari tahun mengalami beberapa kondisi yang berbeda. Berikut adalah data pengangguran dan kesempatan kerja di Indonesia dari tahun 2018 sampai tahun 2020:

Tabel 1. Tingkat Pengangguran (dalam persen) Menurut Jenis Kelamin di Indonesia Tahun 2018-2020

\begin{tabular}{lccc}
\hline Jenis Kelamin & \multicolumn{3}{c}{ Tingkat Pengannguran Terbuka Berdasarkan Jenis Kelamin } \\
\cline { 2 - 4 } & $\mathbf{2 0 1 8}$ & $\mathbf{5 , 2 0 1 9}$ & $\mathbf{2 0 2 0}$ \\
\hline Laki-Laki & $5,34 \%$ & $5,24 \%$ & $7,46 \%$ \\
\hline Perempuan & $5.25 \%$ & $5,22 \%$ & $6,46 \%$ \\
\hline
\end{tabular}

Sumber: (BPS, 2020d)

Dari tabel 1 diatas dapat diketahui pengangguran di Indonesia didominasi oleh laki-laki. Pada tahun 2019 tingkat pengangguran laki-laki adalah sebesar 5,24\% sementara pengangguran perempuan sebesar $5,22 \%$. Pada tahun 2020 , pengangguran laki-laki adalah sebesar $7,46 \%$ sementara pengangguran perempuan sebesar $6,46 \%$. 
Adapun tingkat pengangguran di Indonesia pada tiap-tiap provinsi selama masa Pandemi Covid 19 yaitu pada tahun 2020 sampai 2021 ditunjukkan dalam tabel 2 berikut.

Tabel 2. Tingkat Pengangguran Terbuka Menurut Provinsi (dalam persen) Tahun $2020-2021$

\begin{tabular}{|c|c|c|c|c|c|c|}
\hline \multirow[t]{3}{*}{ Provinsi } & \multicolumn{6}{|c|}{ Tingkat Pengangguran Terbuka Menurut Provinsi (Persen) } \\
\hline & \multicolumn{3}{|c|}{ Tahun 2020} & \multicolumn{3}{|c|}{ Tahun 2021} \\
\hline & Februari & Agustus & Tahunan & Februari & Agustus & Tahunan \\
\hline Aceh & 5,40 & 6,59 & - & 6,30 & - & - \\
\hline Sumatera Utara & 4,71 & 6,91 & - & 6,01 & - & - \\
\hline Sumatera Barat & 5,25 & 6,88 & - & 6,67 & - & - \\
\hline Riau & 4,92 & 6,32 & - & 4,96 & - & - \\
\hline Jambi & 4,26 & 5,13 & - & 4,76 & - & - \\
\hline Sumatera Selatan & 3,90 & 5,51 & - & 5,17 & - & - \\
\hline Bengkulu & 3,08 & 4,07 & - & 3,72 & - & - \\
\hline Lampung & 4,26 & 4,67 & - & 4,54 & - & - \\
\hline Kep. Bangka Belitung & 3,35 & 5,25 & - & 5,04 & - & - \\
\hline Kep. Riau & 5,98 & 10,34 & - & 10,12 & - & - \\
\hline DKI Jakarta & 5,15 & 10,95 & - & 8,51 & - & - \\
\hline Jawa Barat & 7,71 & 10,46 & - & 8,92 & - & - \\
\hline Jawa Tengah & 4,20 & 6,48 & - & 5,96 & - & - \\
\hline DI Yogyakarta & 3,38 & 4,57 & - & 4,28 & - & - \\
\hline Jawa Timur & 3,60 & 5,84 & - & 5,17 & - & - \\
\hline Banten & 7,99 & 10,64 & - & 9,01 & - & - \\
\hline Bali & 1,25 & 5,63 & - & 5,42 & - & - \\
\hline Nusa Tenggara Barat & 3,04 & 4,22 & - & 3,97 & - & - \\
\hline Nusa Tenggara Timur & 2,64 & 4,28 & - & 3,38 & - & - \\
\hline Kalimantan Barat & 4,47 & 5,81 & - & 5,73 & - & - \\
\hline Kalimantan Tengah & 3,33 & 4,58 & - & 4,25 & - & - \\
\hline Kalimantan Selatan & 3,67 & 4,74 & - & 4,33 & - & - \\
\hline Kalimantan Timur & 6,72 & 6,87 & - & 6,81 & - & - \\
\hline Kalimantan Utara & 5,71 & 4,97 & - & 4,67 & - & - \\
\hline Sulawesi Utara & 5,34 & 7,37 & - & 7,28 & - & - \\
\hline Sulawesi Tengah & 2,93 & 3,77 & - & 3,73 & - & - \\
\hline Sulawesi Selatan & 5,70 & 6,31 & - & 5,79 & - & - \\
\hline Sulawesi Tenggara & 3,10 & 4,58 & - & 4,22 & - & - \\
\hline Gorontalo & 3,29 & 4,28 & - & 3,41 & - & - \\
\hline Sulawesi Barat & 2,39 & 3,32 & - & 3,28 & - & - \\
\hline Maluku & 6,71 & 7,57 & - & 6,73 & - & - \\
\hline Maluku Utara & 4,09 & 5,15 & - & 5,06 & - & - \\
\hline Papua Barat & 6,78 & 6,80 & - & 6,18 & - & - \\
\hline Papua & 3,42 & 4,28 & - & 3,77 & - & - \\
\hline Indonesia & 4,94 & 7,07 & - & 6,26 & - & - \\
\hline
\end{tabular}

Sumber: (BPS, 2021)

Dari tabel 2 diatas dapat diketahui bahwa beberapa provinsi dengan tingkat pengangguran terbuka tertinggi pada bulan februari 2020 antara lain: provinsi Aceh dengan tingkat 5,40\%, provinsi Sumatera Barat dengan tingkat 5,25\%, provinsi Kep. Riau dengan tingkat 5,98\%, provinsi DKI Jakarta dengan tingkat 5,15\%, provinsi Jawa Barat dengan tingkat 7,71\%, provinsi Banten dengan tingkat $7,99 \%$, provinsi Kalimantan Timur dengan tingkat $6,72 \%$, provinsi Kalimantan Utara dengan tingkat $5,71 \%$, provinsi Sulawesi Utara dengan tingkat 5,34\%, provinsi Sulawesi Selatan dengan tingkat $5,70 \%$, provinsi Maluku dengan tingkat 6,71\%, dan provinsi Papua Barat dengan tingkat 6,78\%. 
Sedangkan beberapa provinsi dengan tingkat pengangguran terbuka terendah pada bulan februari 2020 antara lain: provinsi Bali dengan tingkat 1,25\%, provinsi Nusa Tenggara Timur dengan tingkat 2,64\%, provinsi Sulawesi Tengah dengan tingkat 2,93\%, dan provinsi Sulawesi Barat dengan tingkat 2,39\%.

Dari tabel 2 diatas dapat diketahui bahwa beberapa provinsi dengan tingkat pengangguran terbuka tertinggi pada bulan februari 2021 antara lain: provinsi Aceh meningkat menjadi 6,30\%, provinsi Sumatera Utara dengan tingkat 6,01\%, provinsi Sumatera Barat meningkat menjadi 6,67\%, provinsi Sumatera Selatan dengan tingkat 5,17\%, provinsi Bangka Belitung dengan tingkat 5,04\%, provinsi Kep. Riau meningkat menjadi 10,12\%, provinsi DKI Jakarta meningkat menjadi 8,24\%, provinsi Jawa Barat meningkat menjadi $8,92 \%$, provinsi Jawa Tengah dengan tingkat 5,96\%, provinsi Jawa Timur dengan tingkat 5,17\%, provinsi Banten meningkat menjadi 9,01\%, provinsi Bali dengan tingkat 5,42\%, provinsi Kalimantan Barat dengan tingkat 5,73\%, provinsi Kalimantan Timur meningkat menjadi 6,81\%, provinsi Sulawesi Utara dengan tingkat 7,28\%, provinsi Sulawesi Selatan meningkat menjadi $5,79 \%$, provinsi Maluku meningkat menjadi $6,73 \%$, dan provinsi Papua Barat dengan tingkat $6,18 \%$.

Dimasa pandemi Covid 19 ternyata sangat berdampak pada tingkat pengangguran terbuka hampir di seluruh provinsi di Indonesia. Bahkan rata-rata tingkat pengangguran terbuka di Indonesia juga mengalami peningkatan, pada periode februari di tahun 2020 tingkat pengangguran sebsar 4,92\% meningkat menjadi 6,26\% pada tahun 2021. Tabel 3 menunjukkan jumlah dan Presentase Penduduk Bekerja dan Pengangguran.

Tabel 3. Jumlah dan Persentase Penduduk Bekerja dan Pengangguran Tahun 2019-2020

\begin{tabular}{|c|c|c|c|c|c|c|c|c|c|c|c|c|}
\hline \multirow{3}{*}{$\begin{array}{c}\text { Penduduk } \\
\text { Bekeria dan } \\
\text { Penganoguran }\end{array}$} & \multicolumn{12}{|c|}{ Jumlah dan Persentase Penduduk Bekeria dan Pengangguran } \\
\hline & \multicolumn{3}{|c|}{2019} & \multicolumn{3}{|c|}{2020} & \multicolumn{3}{|c|}{2019} & \multicolumn{3}{|c|}{2020} \\
\hline & Eebruari. & Aqustus & Tahunaan & Eebruari & Aqustus & Tahounan & Eebruari & Agustus & Jahunan & Eebruari & Agustus & Tahuraan \\
\hline Persentase (\%) & 95,02 & 94,77 & - & 95,06 & 92,93 & - & 4,98 & 5,23 & - & 4,94 & 7,07 & - \\
\hline Jumlah (Ribu orang) & 131692,59 & 128755,27 & - & 133292,87 & 128454,18 & - & 6898,80 & 7104,42 & - & 6925,49 & 9767,75 & - \\
\hline
\end{tabular}

Sumber: (BPS, 2020a)

Berdasarkan tabel 3 diatas dapat diketahui bahwa penduduk bekerja pada bulan agustus tahun 2019 sebesar 94,77\% sedangkan jumlah pengangguran sebesar 5,23\% jumlah penduduk usia kerja di Indonesia. Sementara pada bulan agustus tahun 2020 jumlah penduduk bekerja mengalami penurunan menjadi sebesar $92,93 \%$ dengan kata lain jumlah pengangguran bertambah menjadi $7,07 \%$ dari jumlah penduduk usia kerja di Indonesia. Dari data diketahui bahwa jumlah pengangguran pada bulan agustus 2019 dan agustus 2020 mengalami peningkatan sebesar 1,84\%. 
Tabel 4. Proporsi Lapangan Kerja Informal Sektor Non-Pertanian Menurut Kelompok Umur Tahun 2018-2020

\begin{tabular}{lccc}
\hline $\begin{array}{c}\text { Kelompok Umur } \\
\text { (tahun) }\end{array}$ & \multicolumn{2}{c}{ Proporsi Lapangan Kerja Informal Sektor Non Pertanian } \\
\cline { 2 - 4 } & $\mathbf{2 0 1 8}$ & $\mathbf{2 0 1 9}$ & $\mathbf{2 0 2 0}$ \\
\hline $15-19$ & 42,47 & 38,80 & 57,39 \\
\hline $20-24$ & 27,88 & 25,48 & 33,57 \\
\hline $25-29$ & 31,17 & 31,27 & 34,34 \\
\hline $30-34$ & 38,17 & 38,34 & 42,97 \\
\hline $35-39$ & 43,46 & 43,16 & 46,73 \\
\hline $40-44$ & 47,36 & 47,87 & 50,43 \\
\hline $45-49$ & 50,13 & 50,41 & 53,53 \\
\hline $50-54$ & 51,86 & 51,21 & 53,07 \\
\hline $55-59$ & 57,89 & 57,46 & 60,39 \\
\hline 60 tahun ke atas & 74,63 & 74,23 & 77,20 \\
\hline Rata - rata & 44,19 & 43,84 & 48,57 \\
\hline
\end{tabular}

Sumber: (BPS, 2020c)

Dari tabel 4 diatas dapat diketahui bahwa lapangan in formal sektor non pertanian kerja dari tahun 2018 sampai tahun 2020 didominasi kelompok umur 60 tahun keatas yaitu sebesar 74,63\%, pada tahun 2019; 74,23\% pada tahun 2020 dan sebesar $77,20 \%$ pada tahun 2020 . Sedangkan kelompok usia terendah lapangan kerja in formal sektor non perrtanian kerja dari tahun 2018 sampai tahun 2020 adalah kelompok usia $20-24$ tahun yaitu sebesar $27,88 \%$, pada tahun 2019 ; sebesar $25,48 \%$, pada tahun 2020; dan sebanyak 33,57\% pada tahun 2020 .

Dalam tabel 5 disajikan Proporsi Lapangan Kerja Informal Sektor Non-Pertanian menurut tingkat Pendidikan dari tahun 2017 sampai tahun 2019.

Tabel 5. Proporsi Lapangan Kerja Informal Sektor Non-Pertanian Menurut Tingkat Pendidikan Tahun 2017-2019

\begin{tabular}{cccc}
\hline Tingkat & \multicolumn{2}{c}{ Proporsi Lapangan Keria Informal Sektor Non-Pertanian Menurut Tingkat Pendidikan } \\
\cline { 2 - 4 } Pendidikan & $\mathbf{2 0 1 7}$ & $\mathbf{2 0 1 8}$ & $\mathbf{2 0 1 9}$ \\
\hline$<=$ SD & 66,69 & 66,35 & 65,61 \\
\hline SMP & 52,64 & 53,68 & 53,49 \\
\hline SMA Umum & 36,99 & 37,68 & 38,26 \\
\hline SMA Kejuruan & 29,10 & 31,17 & 30,45 \\
\hline Diploma I/II/III & 17,67 & 18,83 & 19,26 \\
\hline Universitas & 10,48 & 11,48 & 11,63 \\
\hline
\end{tabular}

Sumber: (BPS, 2019)

Dari tabel 5 diketahui bahwa proporsi lapangan pekerjaaan informal sektor non-pertanian didominasi oleh jenjang pendidikan $\leq$ SD dengan rata-rata dari tahun 2017-2019 sebesar 66,22\%. Adapun proporsi lapangan kerja in formal sektor non pertanian jenjang pendidikan $\leq$ SD sebesar $66,69 \%$, pada tahun 2018 , sebesar $66,35 \%$ pada tahun 2019 , sebesar $65,61 \%$ pada tahun 2020 .

Sedangkan lapangan pekerjaaan informal sektor non-pertanian terendah diisi oleh tingkat pendidikan universitas untuk bekerja di lapangan kerja informal jumlahnya cukup rendah yaitu dari tahun 2017-2019 rata-ratanya sebesar $11,20 \%$. Tingkat pendidikan universitas yaitu sebesar 10,48\% pada tahun 2018; sebesar $11,48 \%$ pada tahun 2019 , dan sebesar $11,63 \%$ pada tahun 2020 . Rendahnya tingkat Pendidikan universitas pada lapangan kerja informal sektor non pertanian disebabkan karena tingkat pendidikan universitas lebih banyak mengisi proporsi lapangan kerja formal, yang mana lapangan kerja formal membutuhkan pengetahuan yang tinggi, dimana kualifikasi tersebut dimiliki oleh tingkat pendidikan universitas. 
Tabel 6. Proporsi Lapangan Kerja Informal Sektor Non-Pertanian Menurut Daerah Tempat Tinggal Tahun 2018-2020

\begin{tabular}{cccc}
\hline Daerah Tempat & \multicolumn{2}{c}{ Proporsi Lapangan Keria Informal Sektor Non-Pertanian Menurut Daerah Tempat Tinggal } \\
\cline { 2 - 4 } Tingral & $\mathbf{2 0 1 8}$ & $\mathbf{2 0 1 9}$ & $\mathbf{2 0 2 0}$ \\
\hline Perkotaan & 39,12 & 39,48 & 44,86 \\
\hline Perdesaan & 54,79 & 52,86 & 56,36 \\
\hline $\begin{array}{c}\text { Perkotaan + } \\
\text { Perdesaan }\end{array}$ & 44,19 & 43,84 & \multirow{2}{*}{48,57} \\
\hline
\end{tabular}

Sumber: (BPS, 2020b)

Dari tabel 6 diatas dapat diketahui bahwa proporsi lapangan kerja informal sector non pertanian di pedesaan lebih tinggi dibanding di perkotaan. Hal tersebut bisa jadi dikarenakan masyarakat perkotaan lebih memilih untuk bekerja pada lapangan kerja formal, karena di perkotaan lebih banyak menyediakan lapangan pekerjaan bidang formal dari pada informal.

\section{SIMPULAN}

Dari penelitian diatas dapat ditarik suatu simpulan bahwa: 1) Dari tahun 2018-2020 dapat tingkat pengangguran terbuka berdasar jenis kelamin banyak diisi oleh laki-laki; 2) Rata-rata tingkat pengangguran terbuka di Indonesia juga mengalami peningkatan, pada bulan februari di tahun 2020 tingkat pengangguran sebsar $4,92 \%$ meningkat menjadi $6,26 \%$ pada tahun 2021 ; 3) Jumlah pengangguran pada bulan agustus 2019 dan agustus 2020 mengalami peningkatan sebesar 1,84\%; 4) Lapangan in formal sektor non pertanian kerja dari tahun 2018 sampai tahun 2020 didominasi kelompok umur 60 tahun. 5) Proporsi lapangan kerja informal sektor non-pertanian didominasi oleh jenjang pendidikan $\leq$ SD. 6) Proporsi lapangan kerja informal sektor non-pertanian didominasi oleh daerah yang bermukim di pedesaan

\section{SARAN PENGEMBANGAN PENELITIAN LANJUT (FUTURE RISET)}

Untuk penelitian berikutnya disarankan untuk lebih memperbarui tahun data sehingga hasil datanya bersifat terbaru, selain itu bisa ditambah dengan faktor atau indikator lain agar hasilnya jauh lebih baik dibandingkan dengan penelitian saat ini.

\section{DAFTAR RUJUKAN}

Ahmaddizon, \& Aimon, $H$. (2020). ANALISIS DETERMINAN KESEMPATAN KERJA DAN KEMISKINAN PADA KABUPATEN/KOTA DI SUMATERA BARAT. Jurnal Kajian Ekonomi Dan Pembangunan, 2(4). http://ejournal.unp.ac.id/students/index.php/epb/article/view/10372/4214

Arifin, S., \& Firmansyah, F. (2017). Pengaruh Tingkat Pendidikan Dan Kesempatan Kerja Terhadap Pengangguran Di Provinsi Banten. Jurnal Ekonomi-Qu, 7(2). https://doi.org/10.35448/jequ.v7i2.4978

BPS. (n.d.). Istilah Tingkat Pengagguran. Badan Pusat Statistik. https://www.bps.go.id/istilah/index.html?|stilah\%5Bkatacarian\%5D=pengangguran\&yt0=Tampil kan

BPS. (2019). Proporsi Lapangan Kerja Informal Sektor Non-Pertanian Menurut Tingkat Pendidikan. Badan Pusat Statistik. https://www.bps.go.id/indicator/6/1166/1/proporsi-lapangan-kerjainformal-sektor-non-pertanian-menurut-tingkat-pendidikan.html

BPS. (2020a). Jumlah dan Persentase Penduduk Bekerja dan Pengangguran. Badan Pusat Statistik. https://www.bps.go.id/indicator/6/1953/1/jumlah-dan-persentase-penduduk-bekerja-danpengangguran.html 
BPS. (2020b). Proporsi Lapangan Kerja Informal Sektor Non-Pertanian Menurut Daerah Tempat Tinggal. Badan Pusat Statistik. https://www.bps.go.id/indicator/6/1163/1/proporsi-lapangankerja-informal-sektor-non-pertanian-menurut-daerah-tempat-tinggal.html

BPS. (2020c). Proporsi Lapangan Kerja Informal Sektor Non-Pertanian Menurut Kelompok Umur. Badan Pusat Statistik. https://www.bps.go.id/indicator/6/1165/1/proporsi-lapangan-kerjainformal-sektor-non-pertanian-menurut-kelompok-umur.html

BPS. (2020d). Tingkat Pengangguran Terbuka Berdasarkan Jenis Kelamin. Badan Pusat Statistik. https://www.bps.go.id/indicator/6/1177/1/tingkat-pengangguran-terbuka-berdasarkan-jeniskelamin.html

BPS. (2021). Tingkat Pengangguran Terbuka Menurut Provinsi (Persen). Badan Pusat Statistik. https://www.bps.go.id/indicator/6/543/1/tingkat-pengangguran-terbuka-menurut-provinsi.html

Chandra, A. S., Yulmardi, Y., \& Erfit, E. (2020). Pengaruh pertumbuhan penduduk, inflasi, investasi, upah minimum dan kesempatan kerja terhadap pengangguran di Kota Jambi. Jurnal Paradigma Ekonomika, 15(2), 197-212. https://doi.org/10.22437/paradigma.v15i2.10321

Dona, D. R., Effendi, A. S., \& Muliati, M. (2018). Analisis faktor-faktor yang mempengaruhi kesempatan kerja. Forum Ekonomi, 20(1), 12. https://doi.org/10.29264/jfor.v20i1.3308

Hardini, M. (2017). Pengaruh Pertumbuhan Ekonomi Dan Kesempatan Kerja Terhadap Tingkat Pengangguran Di Kabupaten Sidoarjo. Jurnal Pendidikan Ekonomi (JUPE), 5(1), 1-6. https://ejournal.unesa.ac.id/index.php/jupe/article/view/18325/16708

Herlina, E. (2016). Faktor-faktor yang Mempengaruhi Kesempatan Kerja Wanita dan Implikasinya terhadap Kesejahteraan Keluarga di Kabupaten Cirebon. Jurnal Ekonomi Program Pascasarjana Universitas Borobudur, 18(2), 172-207. https://ejournal.borobudur.ac.id/index.php/1/article/view/293/290

Jalil, A., M, F., \& Kasnelly, S. (2020). Meningkatnya Angka Pengangguran Di Tengah Pandemi (Covid19). Jurnal Ekonomi Syariah, 2(pengangguran akibat covid 19), 45-60. https://berkas.dpr.go.id/sipinter/files/sipinter-1369-123-20200729083625.pdf

Neka, D., Sentosa, S., \& Aimon, H. (2015). Analisis Kesempatan Kerja Sektor Formal Di Indonesia. $\begin{array}{llll}\text { Jurnal Kajian } & \text { Ekonomi, } & 3(6), & \end{array}$ http://ejournal.unp.ac.id/index.php/ekonomi/article/view/5345/4224

Permadhy, Y. T. (2020). Penanganan Permasalahan Pengangguran Pada Desa Bojongcae, Cibadak Lebak. Jurnal IKRA-ITH Ekonomika Vol, 2(3), 54-63.

Priastiwi, D., \& Handayani, H. R. (2019). Analisis Pengaruh Jumlah Penduduk, Pendidikan, Upah Minimum, Dan Pdrb Terhadap Tingkat Pengangguran Terbuka Di Provinsi Jawa Tengah. Diponegoro Journal of Economics, 1(1), 159-169. https://ejournal2.undip.ac.id/index.php/dje

Putu, N. R. P., \& Sudibia, I. K. (2018). ANALISIS DETERMINAN KESEMPATAN KERJA DALAM SEKTOR INDUSTRI DI PROVINSI BANTEN. Fakultas Ekonomi Dan Bisnis, 14(2), 265-283. https://ojs.unud.ac.id/index.php/piramida/article/view/51492/30505

Wikipedia. (2021). Pengangguran. Wikipedia Ensiklopedia Bebeas. https://id.wikipedia.org/wiki/Pengangguran

Yasrizal, ., \& Hasan, I. (2017). Pengaruh Pembangunan Sektor Pertanian Terhadap Distribusi Pendapatan Dan Kesempatan Kerja Di Indonesia. Jurnal IImu Ekonomi Dan Pembangunan, 16(1). https://doi.org/10.20961/jiep.v16i1.2320 